\title{
An analysis of Gentlemen and Fighter of British and American Literature in the Literary Works
}

\author{
Rui Liu, Liping Tian \\ School of foreign languages, Hebei University of Technology, Tianjin, 300430, China
}

Keywords: Literature, British and American literature, Gentleman, Fighter

\begin{abstract}
In the history of world literature, the importance of English and American literature plays an irreplaceable role. Because of the influence of many factors, the British and American literary works have also formed a unique feature, which has a very strong mark, and the most notable is the British gentlemen complex and the American fighter complex. The paper firstly introduces the gentlemen complex and the fighter complex respectively of British and American literature, and then analyzes the common points and differences, which aims to understand the connotation of the two kinds of complex, in order to deepen the understanding of British and American culture.
\end{abstract}

\section{Introduction}

The uniqueness of the British national culture is a gentleman, contains the spirit of perseverance and fighting, gentility was produced in the fusion of social common values, the fusion process was continuous. The American culture has a very strong diversity, especially in the literary works, which is called the fighter complex. Although there are great differences between gentleman complex and fighter complex, but there is also something in common, the study of gentleman complex and fighter complex in the literature works has very important value and significance to understand the British and American culture.

\section{An analysis on the British gentleman complex in the literary works}

The British gentleman complex can be traced back to fifteenth Century, influenced by a lot of factors; the connotation of the gentleman was constantly changing. It was originally from the descent and property to determine the position of a gentleman. In the Queen Victoria era, the rise of the United Kingdom Empire, in which cannot be overlooked was gentleman group strength. At this stage, the gentleman began to be recognized by the majority of people. After the 19th century, great changes took place in judging the standard of a gentleman, the gentleman without distinction, as long as a person's behavior was elegant, generous style of conversation, with noble personality could be thought as a gentleman. It was in this period that the concept of gentleman began to be clear. Can be seen, in the history of the United Kingdom, there was gentleman complex from beginning to end, and has become a typical male image, so in the literary works, of course, the description of the gentleman was indispensable.

Knight literature. The knight literature is the beginning of gentleman complex, began in the 11th century, when the knight pledged to fight to the death to defend their honor and would do anything for his lover, which fully reflects the characteristics of courteous gentleman. The first description of the knight is "Beowulf" long poem, in the poem depicted the typical image of knight, and contained all the qualities of a gentleman. Another representative work is "Lancelot", in the book described the Knight's deep love to the Queen, and showed the knight's loyalty to love. Although the knight system disappeared in a long time ago with the development, but the knight's image has not disappeared, but gradually deepened, honest, heroic, sacrifice and so on were the core of the current gentleman complex.

Gentility. In the middle ages, the knight spirit gradually turned to gentility. In this period, the gentleman's image developed into the most prosperous state in literary works. It was also the first time that the British gentleman, which was known by the public, fully embodies the value of honor, and the belief of ideal and freedom. In "Romeo and Juliet" vividly showed gentility and gentleman 
complex, which has such a sentence: "your lover said - he said very much like an honest gentleman, very polite, very polite, very beautiful and well behaved." Can be seen, gentility had formed at that time. Still a representative of Fielding “Tom's Jones”, in the book, Fielding presented his views and standard of gentleman, although Tom was not moral incarnation, not a full sense of the gentleman, but in his body fully showed the human nature, this is the kernel of gentleman character.

Gentleman image. Refers to gentleman image, cannot but mentioning the British fantasy literature, including "the Lord of the Rings", "Harry Potter" and so on. In these works, the hero loves adventure, dare to struggle with the evil forces, and fully presents a gentleman's temperament, interpretation of the meaning of the British gentleman. British magic literature is based on the historical background, such as in the "The Chronicles of Narnia", the background is United Kingdom in World War II period. British geographical culture impact on the literary works is very large, such as in "the Lord of the Rings", elfin Legolas is very typical gentleman and the man who played the role was authentic British, with gentle personality, advocating freedom, fully meet the gentleman characteristics. All in all, the cultural characteristics of the United Kingdom have created British gentleman's image, and the gentleman image and gentlemen complex could not be divided in literary works, which would be accompanied by the development of British literature.

\section{The analysis of American fighter complex in the literary works}

Origin of fighter. America is a country of immigrants, not only has the characteristics of cultural diversity, the literature also has this feature, and it is because of the American history formed fighter complex which is different of gentleman. Fighter complex contains dream of freedom of the Americans, a lot people hoped achievements first came to the colony, through the cooperation and competition between people won this piece of land, so in the American literature basically contain fighter complex.

Cowboy is the origin of the American fighter, the most prosperous period was about 1885, although at that time the cowboy only appeared in the west, but the United States did not have boundaries, so later cowboys throughout the United States. Under the influence of the westward movement in the United States, the animal husbandry in the West began to develop and fighter cowboy image was familiar by more and more people. Initially most of them were young people, who herd cattle as the main source of life, in the harsh living environment; they formed firm and tenacious character. Then the cowboy became incarnate and justice also appeared more and more fighter image in the American literature. For example, of American writer Kolb's five stages is one of the representatives of cowboy image. His work took the fight between the local people and the colonists as the subject reflected the American historical process. His work not only inspired the American love to the country, but also led the development of literature at that time, and formed the climax of western novels.

\section{The formation of fighter image.}

Fighter's soul - political comment literature

In American war of independence, the most prominent literature was political comment literature. At this stage, America was relatively weak, political comment literature played a very significant role in incentive. Such as Paine's pamphlet "common sense" was a prominent representative work, although the fighter image had not reveal in the prevailing political comment literature, but by political comment literature, greatly inspired morale, created fighter's soul, made fighter full of strength when fight for freedom of the country, this kind of struggle spirit of not giving up became main literature core in future.

The fighter's flesh and blood - the literature of the Civil War

During the Civil War, American literature entered a new peak, a lot of popular literature works appeared, such as "the adventures of Tom", "gone with the wind" and so on. Take "gone with the wind" as an example, the hero Rhett Butler is a typical "fighter", with a clear understanding and rational analysis in the war, brave, intelligent, and fully demonstrated the spirit of a man. These were all the remarkable features of the American fighters, which can be seen, the fighter complex reflected the desire of Americans for freedom. 
Fighter image - contemporary American literature

After the Second World War, the development of American literature was more prosperous. In this stage, the art pattern was constantly innovating and developing. All kinds of schools and various forms of literature emerged endlessly. For example: Lawrence Block on behalf of the detective fiction occupies high literary position, runs throughout the novel is a "tough guy" characteristics, usually appears image that hero breaks through hazardous spot and heroic detective, fully reflects the characteristics of American fighter complex, greatly expressed the sense of justice and heroism. In addition, in the American film the embodiment of the fighter complex is also very much, such as "Indiana Jones" and so on.

\section{The common ground between the gentleman complex and fighter complex in the literary works}

The pursuit of fairness. On the whole, the gentleman and the fighter were all trying to pursue fair in the competition, would not take any harm the interests of others to achieve their purpose. In terms of the gentleman and fighter, opportunistic and selfish practices belong to the villain, which was the behavior of contempt by others; this concept in a duel was more prominent. If there was a contradiction between the two gentlemen, they would settle by a duel, and in a duel the basic principle of fair competition will be fully observed. Therefore, in the British and American literature, this kind of pursuit of justice was very normal, the gentleman and the fighter were the representatives of just of Britain and America, all damage acts and means to others would not happen to them.

Respect for women. In literature, the image of women more was petite and delicate, soft and weak, but cannot deny is, by the attitude of women in literary works can see the cultural character of the country. In old China, the male power was prominent; in the literary works also showed men's authority, in most cases women were oppressed by men. And in British and American literature, shows more respect and protection for women, whether gentleman or fighter, the identity was the protector of women and the story always was "the hero rescue the beauty". For example: in the British literature, the knight would regard his beloved people as the apple of the eye, willing to do anything for love; in American literary works was the same, often was the cowboys struggle with evil for lover.

The pursuit of freedom. From the British history we can see that the gentleman completely inherited the spirit of the British aristocracy, bravely pursued freedom. British history has always been consistent with the idea of opposition to dictatorship and the pursuit of freedom, from parliamentary system to the constitutional monarchy system, reflected the gentleman's spirit of coming out boldly for freedom. This spirit also had fully reflected in the American fighters, because Americans had a strong desire for pursuing freedom, they could smoothly come out of the British colonies, and obtained real freedom. American revolutionary Patrick Henry was on the eve of the American Revolution shouted out slogan "give me liberty or give me death", either picked up weapons gained independence, or compromised and enslaved. The slogan inspired the morale of the Americans, and fighters' pursuit for freedom was casted in American culture. Cowboy was the outstanding representative of fighters, cowboy came out from their familiar life and hometown to West and explored their new life, when encountered at the sight of injustice would draw a sword and render help, they had a strong sense of justice and ready to help the weak, fight for freedom, equality and independence.

\section{The difference between the gentleman and the fighter in the literary works}

There were a lot in common between gentleman complex and fighter complex, but it is necessary to analyze the differences between them.

The tradition of the gentleman complex - the exploration of fighter complex. 3500 years ago, there had been human habitation in British island, where had a very long history, so, also retained a lot of tradition in the British gentleman, these traditions were regarded as treasure by them, was not allowed to be questioned, in the literary works also showed the noble attitude and pride. Relative to Britain, the development history of America is only a few hundred years, not impacted by red tape, and there was no tradition to be abided, so compared with gentleman fighter had a strong pioneering 
spirit.

Restraining of gentleman complex -- Publicity of fighter complex. In British literature, British gentleman in the face of his beloved girl would recite poems for her, and invite her to dance, such as in Shakespeare's "Romeo and Juliet", the confession when Romeo firstly met Juliet, fully reflected the gentleman's humble and polite, every word of the conversation were very subtle. And in the American literature, more was like Rhett Butler in "Gone with the wind", the way of expression was very warm and open, bold and daring to express his love of the girl. Restraining of gentleman complex brightly contrast with publicity of fighter complex, the tradition and open were caused by the traditional culture.

Stratum Consciousness of gentleman - equal consciousness of fighter complex. In British literature, the gentlemen had very noble temperament, with high position, not only had elegant demeanor, but also had knowledge the ordinary people did not have, the main reason was that Britain was influenced by traditional ideology, the idea of hierarchy was deep-rooted to now. In American literature, the fighters usually appeared in the more popular places, such as bars, fighters could get along very well with all kinds of people. This is precisely because America is an independent country, the idea of everyone is equal had been around, the nations are also more integrated, with a very strong sense of equality.

\section{Conclusion}

Through the above analysis can be seen the gentleman complex and fighter complex in British and American literature depending on their respective cultural background, British literature showed handsome gentleman complex, and American literature showed the image of brave fighters. But cannot deny is that British and American are the same vein, and British and American literature are a flourishing geminate flower, through the complex analysis in literary works of the two countries expressed to guide people to learn more about British and American culture, and also has a very important value on the development of other aspects of Britain and America.

\section{References}

[1] Dai Hongbo. Spy people from books: comparison of the gentleman and fighter in the British and American literature. Academic exchange, 2013 (04): 198-201.

[2] Zhang Xiaohang, Zhang. Lingling. The comparison between of British gentleman and American fighter in the view of literature development.Writer, 2015 (12): 178-179.

[3] Yan Yi. The Greek literature and Hebrew literature - on the basis of British and American literature. Overseas English, 2012 (21): 194-195.

[4] Wang Yuanyuan. Spy people from books: comparison of the gentleman and fighter in the British and American literature. Anhui Literature (the second half of the month), 2015 (05): 151-152.

[5] Hu Yinglin. The comparison analysis of the two characters of the gentleman and fighter in the British and American literature. Northern literature journal, 2013 (01).

[6] Zhao Qiaohong. Explore and analyze the gentleman and fighter based in British and American literature perspective. Mangzhong, 2014 (19): 65-66.

[7] Lu Rong. "Greek and Hebrew” complex in British and American literature - Greek literature and Hebrew literature. Mangzhong, 2012 (23): 95-96. 